\title{
Evaluation of Land Subsidence Impact at Lowland Areas Using Analitycal Hierarchy Process (AHP) Method
}

\author{
Andriani $^{1,2}$, Eddy Ibrahim $^{3}$, Dinar Dwi Anugerah Putranto ${ }^{4}$, and Azhar Kholiq Affandi ${ }^{5}$ \\ ${ }^{1}$ Postgraduate Program of Environmental Science, Universitas Sriwijaya, Palembang, Indonesia \\ ${ }^{2}$ Civil Engineering Departement, Andalas University, Padang, Indonesia \\ ${ }^{3}$ Minning Engineering Departement, Universitas Sriwijaya, Palembang, Indonesia \\ ${ }^{4}$ Civil Engineering Departement, Universitas Sriwijaya, Palembang, Indonesia \\ ${ }^{5}$ Physics Departement, Universitas Sriwijaya, Palembang, Indonesia
}

\begin{abstract}
Land subsidence is a problem that often occurs in lowland areas. The impact of land subsidence causes losses in the economic, physical, ecological and social aspects. The impact of land subsidence could be felt directly and indirectly by the people, so an evaluation of the most frequent (dominant) impacts needs to be done. One method that could be use for assesment using AHP, using pairwise comparisons can be obtained the most frequent (dominant) land subsidence impact. From the results of the study indicate that the direct impact due to land subsidence (weight 0.608)) is more dominant than the indirect impact (0.392). Based on the value of each parameter, three dominant land subsidence impacts are infrastructure damage with a value of 0.387 , an increase in the cost of infrastructure construction and maintenance with a value of 0.193 and a flood of 0.129. The results of observations and ground checking at the Tanjung Api-Api area, there was damage to several floors of residents' homes, damage to road and tilt of trees which were damaged in the economic field was the most dominant impact. While floods and seawater intrusion are not dominant in this area because the area is located in the tidal area.
\end{abstract}

\section{Introduction}

Tanjung Api-Api is one of the lowland areas in South Sumatra which is located on the east coast of Sumatra Island. Lowlands have a crucial function into environmental management because lowlands are able to accommodate and provide water, prevent coastal abrasion, prevent sea water intrusion, oxygen providers and have unique biodiversity $[1,3]$. Development of lowlands to be built-up areas will trigger various problems, one of it is land subsidence. Land subsidence causes direct and indirect impacts to environment, such as infrastructure damage as cracks in buildings and floor, cracks on the road, damage to drainage and increased of construction costs $[4,5,6]$ and also causing flooding and widespread flood areas, sea water intrusion, damage to the drainage system and caused 
deformation at building construction so that it has an impact on the economic and social life $[2,9,10,11,14,15,16]$.

To evaluate the dominant/ crucial impact of land subsidence could be used Analitycal Hierarchy Process (AHP) Method. Analitycal Hierarchy Process is a multilevel structure method in determining decisions using complex multi criteria. Evaluation of land subsidence impact is very crucial to determine the appropriate mitigation strategy. The weighting and scoring of each parameter will make it easier to determine the decision to be chosen [13].

The analytical hierarchy process and sensitivity analysis (AHP-SA) could be used to evaluated the risk of land subsidence, with weighting and scoring from multicriteria parameters of causes of land subsidence [11]. To determine the weight of all criteria in the assessment of the hazard of land subsidence, it is done by fuzzy AHP so that the consistency of the matrix and convergence speed have a high degree of accuracy [7]. To solve the problem of assessment matrix consistency and factor weight uncertainty could be used an improved fuzzy analytic hierarchy process, so that it could evaluate the risk of land subsidence and the related preventive measures are adopted [8]. Disaster Risk Assessment is carried out using Analytic Hierarchy Process (AHP) and GIS can help in developing prevention and risk management techniques [12].

Changes in land use/land cover due to the development of the Tanjung Api-Api area as a special economic area caused environmental degradation. Land subsidence is caused by several factors, namely natural and human factors $[1,3,4,5,6,12]$. The conversion of lowlands to built-up areas will lead to increased building loads, increased population and increased demand for water so that it can trigger land subsidence in the region. To determine the vulnerability of the area due to land subsidence and the impact it will cause, an evaluation needs to be done, one of which is by using the Analytic Hierarchy Process (AHP) method.

\section{Materials and Methods}

The data used in this study are primary data in the form of questionnaires from geotechnical, environmental and construction experts. The number of experts used in this study were 10 expert. Weighting each criterion is done using AHP. To validate AHP results, field observations and ground check were carried out in the field. The steps for completing AHP are as follows:

a. Literature review to determine the impact of land subsidence

b. Establish a hierarchical structure of land subsidence impact. Decision Making hierarchy consisting of:

- Level 0 is the goal 1 of the decision making process

- Level 1 is a decision-making criterion, both quantitative and qualitative criteria.

- Level 2 is a sub-criterion that describes the parts of the criteria

- Level 3 is the alternatives that will be covered or decided in the research.

c. Weighting of the predetermined criteria by comparing criteria one with other criteria (pairwise comparation) with AHP scale 1 to 9.

d. Checked of the consistency ratio of each questionnaire ( $\mathrm{CR}<0.1$, if $\mathrm{CR}>0.1$ then the questionnaire must be repeated).

e. Calculating of the geomean of each parameter by using the formula:

$$
\text { Geomean }=\left(\mathrm{y}_{1} \cdot \mathrm{y}_{2} \cdot \mathrm{y}_{3} \ldots . \mathrm{y}_{\mathrm{n}}\right)^{1 / \mathrm{n}}
$$

Where as : $\mathrm{y}_{1}=$ expert $1, \mathrm{y}_{2}=$ expert $2, \mathrm{n}=$ number of experts 
f. After of obtained the main priority in the form of the dominant of land subsidence impact, then validation is carried out by conducting observations and checking in the field.

Figure 1 showed the hierarchical structure of the assessment of land subsidence impact using the Analitycal Hierarchy Process (AHP) method.

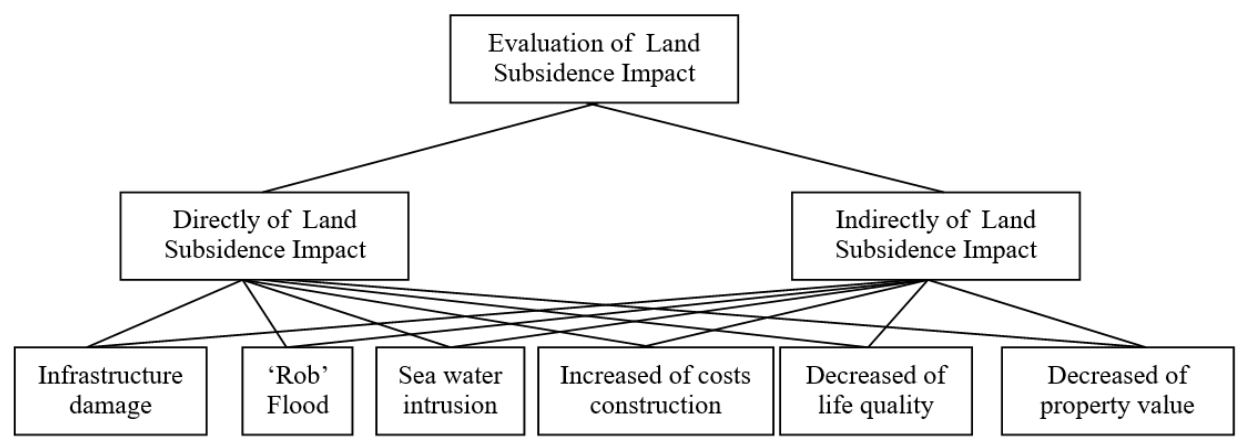

Fig. 1. Decision of hierarchy based on Analitycal Hierarchy Process (AHP) Method.

After obtained result of the dominant impact of land subsidence using the AHP method, and then validation is done by observed the impact of land subsidence that has occurred in the area of Tanjung Api-Api. Figure 2 showed the location of observations in the field.

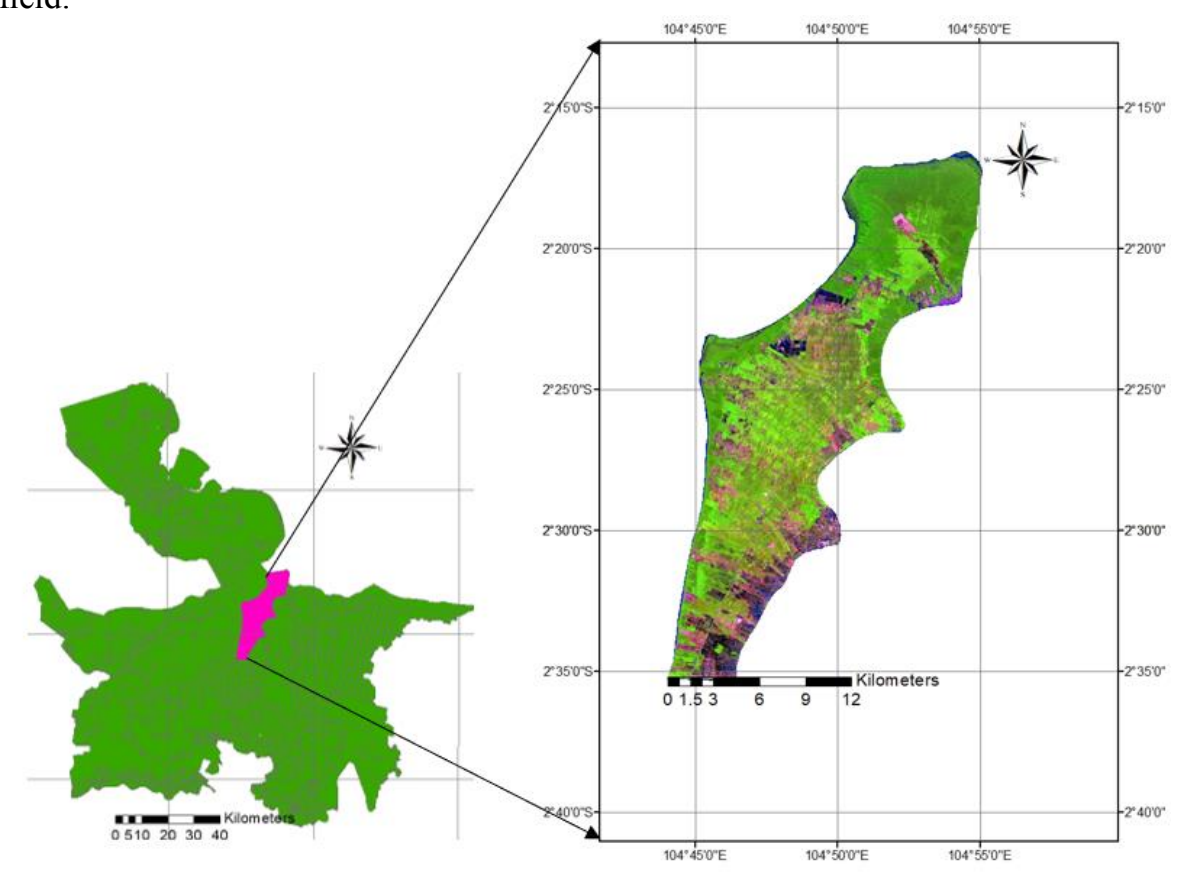

Fig. 2. Location of Study Area at Tanjung Api-Api. 


\section{Results and Discussions}

Land subsidence could caused technical and non-technical impacts, causing economic and social losses. The impact of land subsidence could be felt directly and indirectly by the people. In general, technical and environmental impacts are impacts that are felt directly by the community, such as damage to buildings/infrastructure, tidal flooding and sea water intrusion. While the economic and social impacts were impacts that are not directly felt by the people. AHP is one solution that could be used to evaluated dominan impact of land subsidence. Table 1 showed the results of the land subsidence impact with AHP.

Table 1. Results of Evaluation Land Subsidence Impact Using with AHP.

\begin{tabular}{|c|c|c|}
\hline Impact of Land Subsidence & Weight & Score \\
\hline Direct Impact of Land Subsidence & & 0.638 \\
1. Damage of Infrastructure & & 0.211 \\
2. Rob Flood & $\mathbf{0 . 6 0 8}$ & 0.151 \\
3. Intrusion of Sea Water & & \\
Indirect Impact of Land Subsidence & 0.491 \\
Increased costs of construction and maintenance \\
$\begin{array}{c}\text { of infrastructure } \\
\text { 2. Decreased of life quality }\end{array}$ & $\mathbf{0 . 3 9 2}$ & 0.311 \\
Decreased of property and infrastructure value & & 0.198 \\
\hline Total & \\
\hline
\end{tabular}

Table 1 showed that the direct impact of land subsidence is more dominant than indirect impacts, direct impacts are impacts that can be felt and seen directly by the community. In Figure 3, the direct impact that dominan occurs due to land subsidence is damage to buildings / infrastructure compared to the effects of tidal floods and intrusion of sea water.

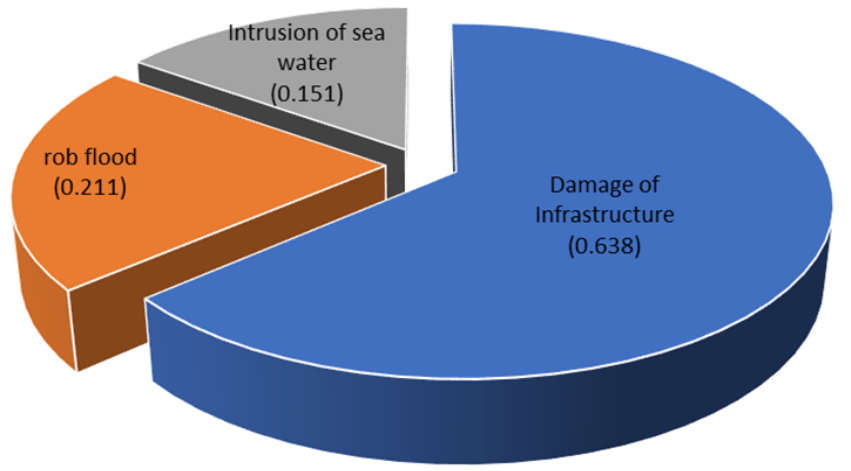

Fig. 3. Evaluation of Direct Impact of Land Subsidence with AHP.

Observations at Tanjung Api-Api area showed that the impact of land subsidence that had been felt by the people at the study area was the presence of cracks on the floor of the house/office building Figure $4 \mathrm{a}$, damage to several road sections Figure 4b, and many coconut trees is tilt Figure 4c. 


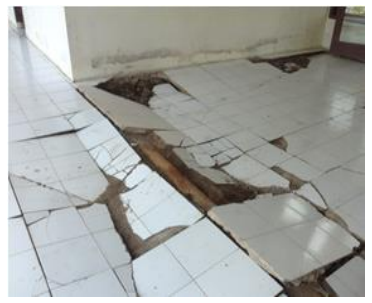

(a) Cracking on Floor Housing

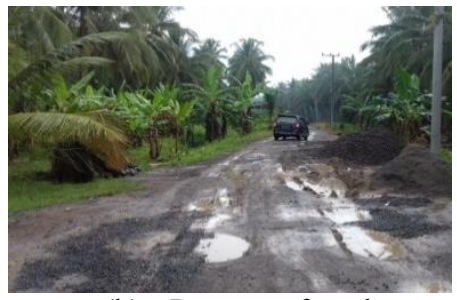

(b) Damage of road

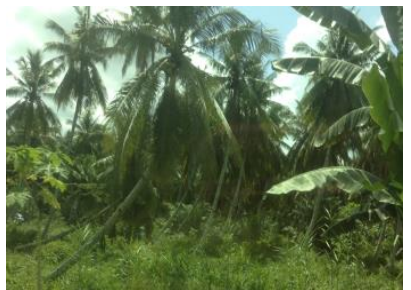

(c) Coconut trees is tilt

Fig. 4. Direct Impact of Land Subsidence.

The results of the assessment with AHP provide significant results with observations in the field that the dominant impact that occurs is damage to infrastructure. Based on observations in the field results obtained that during the dry season the taste of water is salty because to the entry of sea water into the river but not due to sea water intrusion, it is because this area is in tidal areas and flooding often occurs due to tides but quickly dries.

The indirect impact of land subsidence is the increased cost of infrastructure construction and maintenance with a weight of 0.491 . The higher the damage to infrastructure causes the greater costs required to repair damage to buildings, roads and other infrastructure. The costs of maintenance for infrastructure and facilities are higher and special construction is needed to deal with the damage. The direct impact of land subsidence caused a decrease in quality of life and the environment such as health, sanitation and comfort conditions with a weight of 0.31 and caused a decrease in the value of property and infrastructure.
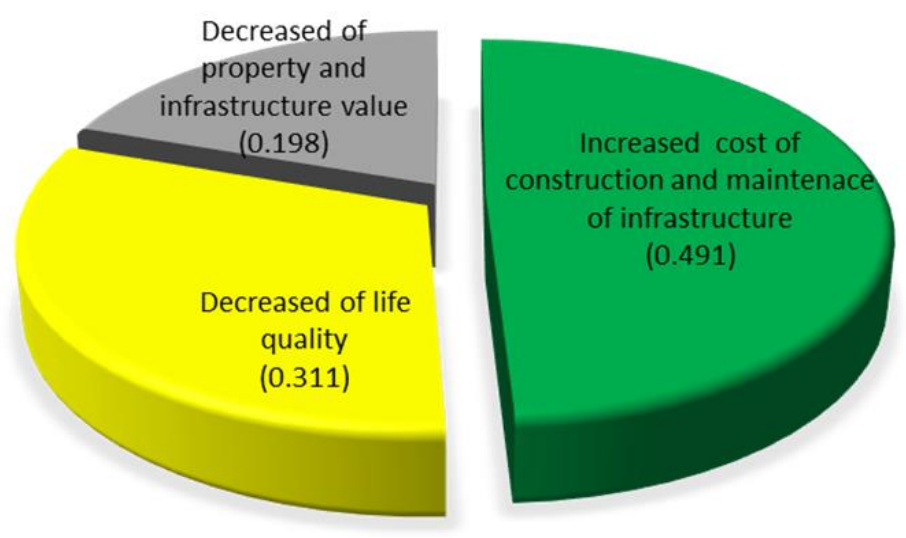

Fig. 5. Indirect Impact of Land Subsidence.

Figure 6 showed the results of the overall evaluation of land subsidence impact. The results from the multiplication between the weight of the criteria with the subcriteria score showed that there are three dominant impact that will occur due to land subsidence i.e. infrastructure damage, increased costs of infrastructure development and maintenance and flooding caused by tidal. 


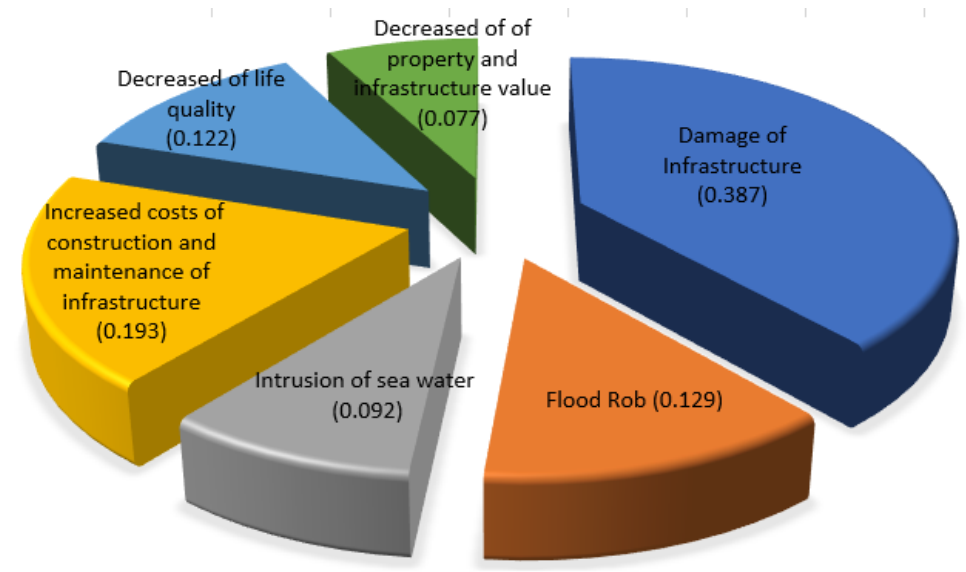

Fig. 6. The Overall Evaluation of Land Subsidence Impact.

Evaluation of land subsidence impact using the AHP method provides significant results with observations in the field. AHP Method can be used to assess the risks and impacts of land subsidence so that could be determined the most appropriate mitigation method in lowland areas.

\section{Conclusions}

Lowland is the area that susceptible to land subsidence, based on the AHP method and observations at study area gave the conclusions are following : 1) the direct of land subsidence impact (weight 0.608) was more dominant than the indirect impact (weight $0.392)$, 2)the most of directly impact occurs was the most damage to infrastructure with a weight of 0.638 . While the indirect impact due to the most dominant land subsidence is the increase in the cost of infrastructure construction and maintenance with a weight of 0.491 , 3 ) the results of observations in the Tanjung Api-Api area showed that the dominant impact of land subsidence is damage to buildings and crack of the road, while sea water intrusion and occur of flooding very small,and 4) the Analytical Hierarchy Process (AHP) method could be used to evaluated the dominant impact of land subsidence, because it provides significant results with observations in the field.

\section{Acknowledgments}

On this occasion the author would like to thank for all the experts who have been involved and supported this research.

\section{References}

1. A. Fulton, Land Subsidence : What is It and Why is It an Important Aspect of Groundwater Management (griculture and Natural Resources, University of California, 2006)

2. F. Raspini, C.Loupasakis, D.Rozos and S.Moretti. J. Natural Hazards and Earth System Science 13 (2013)

3. F. Yulianto, M.A. Marfai. Jurnal Ilmiah Geomatika 17 (2015) 
4. H. Z. Abidin1, I. Gumilar1, H. Andreas1, D.Murdohardono and Y.Fukuda. J. Environ Earth Sci 68 (2013)

5. H. Z. Abidin 1, H. Andreas1, I. Gumilar1, and J. Brinkman. J. IAHS 372 (2015)

6. I. Gumilar, H.Z. Abidin, T.P.Sidiq, H.Andreas, R.Maiyudi, M.Gamal and Y.Fukuda, Journal of Geospatial 2 (2013)

7. H.M. Wang, Y.Wang, X.Jiao and G.R. Qian. J. Desalination and Water Treatment 52 (2014)

8. J. Liu, H. Wang and X.Yan J. IAHS 372 (2015)

9. K.Karila, M. Karjalainen, and J. Hyyppa. Journal of Finland 19, 2 (2005)

10. L.Bayuaji, J.T.S.Sumantyo and H.Kuze. J. Canadian Journal Remote Sensing 36, 1 (2010)

11. L.Zhu, Y.Chen, H.L. Gong, C.Liu and R.Wang, Spatial risk assessment on land subsidence in Beijing, China, 20th (International Congress on Modelling and Simulation, Adelaide, Australia, 2013)

12. R. Bhattarai, A.Kondoh.J. Advances in Remote Sensing 6 (2017)

13. T.L.Saaty. J. Services Sciences 1, 1 (1980)

14. Y.Yang. J. Urban Geol 1 (2015)

15. Y.Ito, H.Chen, M. Sawamukai, T.Tokunaga. J. Proc. IAHS 372 (2015)

16. Z. Ramadhanis, Y. Prasetyo, B.D. Yuwono, Analisis Korelasi Spasial Dampak Penurunan Muka Tanah Terhadap Banjir Di Jakarta Utara (Jurnal Geodesi Undip , 2017). 